\title{
Alternaria brassicae Produces a Host-Specific Protein Toxin from Germinating Spores on Host Leaves
}

\author{
R. Y. Parada, E. Sakuno, N. Mori, K. Oka, M. Egusa, M. Kodama, and H. Otani
}

First, third, and fifth authors: The United Graduate School of Agricultural Sciences, Tottori University, Tottori 680-8553, Japan; second, fourth, sixth, and seventh authors: Faculty of Agriculture, Tottori University, 4-101 Koyama-Minami, Tottori 680-8553, Japan. Accepted for publication 27 November 2007.

\section{ABSTRACT}

Parada, R. Y., Sakuno, E., Mori, N., Oka, K., Egusa, M., Kodama, M., and Otani, H. 2008. Alternaria brassicae produces a host-specific protein toxin from germinating spores on host leaves. Phytopathology 98:458463.

Spore suspensions of Alternaria brassicae, the causal agent of gray leaf spot in Brassica plants, were incubated on the leaves of cabbage (B. oleracea) and spore germination fluid (SGF) was collected after $48 \mathrm{~h}$. A high molecular weight (HMW) fraction (>10 kDa) was separated from the SGF by ultrafiltration. In a detached leaf assay, the HMW fraction induced visible symptoms only on host leaves and the toxicity was lost by treatment with proteinase $\mathrm{K}$ or heat at $60^{\circ} \mathrm{C}$ for $15 \mathrm{~min}$, indicating the presence of host-specific protein toxin(s). A protein toxin in the HMW fraction was purified by several chromatography steps. The toxin induced water-soaked symptoms followed by chlorosis at concentrations of 0.5 to $1 \mu \mathrm{g} / \mathrm{ml}$ on host leaves, but not on nonhost leaves even at $50 \mu \mathrm{g} / \mathrm{ml}$. The toxin also had infection-inducing activity when added to spore suspension of a nonpathogenic isolate of A. alternata, causing symptoms similar to the infection of $A$. brassicae only on host leaves. These results indicate that a new host-specific protein toxin named ABR-toxin is released from germinating spores of $A$. brassicae on host leaves. ABR-toxin migrated as a protein of $27.5 \mathrm{kDa}$ by sodium dodecyl sulfate-polyacrylamide gel electrophoresis. The isoelectric point of ABR-toxin was estimated to be approximately 7.0 and $21 \mathrm{~N}$-terminal amino acid residues were sequenced.
Certain fungal pathogens, especially the genera Alternaria and Cochliobolus are known to produce host-specific or host-selective toxins (HSTs) $(13,22,24,26-29)$. HSTs are toxic only to the host plants, and have an important role in pathogenesis as primary determinants of virulence or pathogenicity $(11,13,17,18,27-30)$. The majority of HSTs are low-molecular-weight secondary metabolites belonging to various classes of chemical compounds, and have been extracted from liquid cultures. However, production of toxins by germinating spores on host plants suggests the very early participation of toxins at the site of the initial contact of the pathogen and host surface $(14,15)$. Among HSTs, Alternaria brassicicola and A. panax produce protein HSTs named AB-toxin (20) and AP-toxin (23), respectively. Interestingly, ABtoxin is released from germinating spores on host plants, but not on nonhost plants or in culture media (20). The production of APtoxin also is detected only on host plants during the spore germination (23). Recently, Oka et al. (16) reported that production of AB-toxin by germinating spores is induced by a host-derived oligosaccharide.

A. brassicae (Berk.) Sacc., the causal agent of gray leaf spot, is one of the most important diseases in Brassica spp. worldwide $(3,7,25)$. The symptoms of the disease are lesions with grayish, brownish, or blackish centers and chlorotic margins on the leaves, stems, and siliques (25). The pathogen has been reported to produce four phytotoxins, which are low molecular weight cyclodepsipeptides named destruxins $(1-3,5,25)$. Destruxin $B$ is the major phytotoxin produced by the pathogen in liquid culture, and the three other phytotoxins, homodestruxin $\mathrm{B}$, destruxin $\mathrm{B}_{2}$, and

Corresponding author: H. Otani; E-mail address: otani@muses.tottori-u.ac.jp

* The $e$-Xtra logo stands for "electronic extra" and indicates that Figure 4 appears in color online.

doi:10.1094/PHYTO-98-4-0458

(C) 2008 The American Phytopathological Society desmethyldestruxin are produced in much smaller amounts (25). Bains and Tewari (3) reported that destruxin B is toxic to Brassica plants but not to nonhosts, and the order of sensitivity of different Brassica plants to destruxin B is similar to their order of susceptibility to the pathogen. Based on these observations, they classified destruxin B as a HST. In contrast, Buchwaldt and Green (5) reported that the activity of destruxin B is nonspecific, although Brassica plants are the most sensitive and the sensitivity decreases as relatedness of Brassica groups becomes more distant. Our recent study (21) indicated that destruxin B is a nonspecific toxin supporting the result of Buchwaldt and Green (5), and does not induce the initial colonization of the plant by the pathogen.

A. brassicae has a similar host range as that of $A$. brassicicola, which produces AB-toxin in spore germination fluids (SGFs) on the host plants (20). Therefore, we investigated the presence of HST(s) in SGFs of A. brassicae on host plants, and we found a new protein HST named ABR-toxin different from AB-toxin. This study describes the detection and purification of ABR-toxin from germinating spores of $A$. brassicae. In addition, the biological activities and chemical characteristics of the toxin are reported.

\section{MATERIALS AND METHODS}

Fungal and plant materials. A. brassicae isolate O-265 was originally obtained from diseased cabbage (B. oleracea) in the Research Institute, Takii \& Co. Ltd., Japan, and selected for its ability to produce abundant spores in agar medium. A nonpathogenic isolate O-94 of A. alternata, a stock culture in our laboratory was also used. These isolates were maintained on potato dextrose agar (PDA) slants at room temperature $\left(25 \pm 2{ }^{\circ} \mathrm{C}\right)$ in the dark. A subculture of the isolate O-265 was grown on V8 juice agar medium containing $0.004 \%$ Rose Bengal in petri dishes $(9$ $\mathrm{cm}$ diameter), and incubated for 2 to 3 weeks at $20^{\circ} \mathrm{C}$ under a $16 \mathrm{~h}$ dark and $8 \mathrm{~h} \mathrm{UV}$ light (black fluorescent light, FL-20SBLB, 
Toshiba, Tokyo, Japan) period. A subculture of the isolate O-94 was grown on PDA medium and incubated for 2 to 3 weeks at $25^{\circ} \mathrm{C}$ in the dark.

Cruciferous plants; komatsuna (B. campestris) cv. Rakuten, cabbage (B. oleracea) cv. Shoshu, oilseed (B. napus) cv. Westar, and Japanese radish (Raphanus sativus) cv. Taibyo-Soubutori were used as host plants. Tomato (Lycopersicon esculentum) cv. Momotaro, apple (Malus pumila) cv. Red Gold, and Japanese pear (Pyrus pyrifolia) cv. Nijisseiki, were used as nonhost plants. Seeds were grown in pots containing a mixture of commercial soil and vermiculite $(2: 1, \mathrm{wt} / \mathrm{wt})$, and transferred in an incubation room at $25^{\circ} \mathrm{C}$ for 3 to 4 weeks under a $16 \mathrm{~h}$ light and $8 \mathrm{~h}$ dark period. The second and third leaves were detached and used for assays. The young leaves of Japanese pear and apple were collected from annual seedlings planted in pots and maintained in a glasshouse.

Preparation of spores and pathogenicity tests. The spores of O-265 and O-94 were collected separately as described by Otani et al. (20). The subcultured dishes were flooded with distilled water (DW), and the surfaces were brushed with a small paintbrush. The spore suspensions were filtered through three layers of cheesecloth to remove the mycelium debris, and the spores were washed twice in DW by centrifugation (Himac CF 7D2, Hitachi, Tokyo, Japan) at $800 \mathrm{~g}$ for $5 \mathrm{~min}$. The spores collected on Whatman filter paper No. 50 were airdried and stored at $-80^{\circ} \mathrm{C}$ until use.

For pathogenicity tests, the spore suspensions were counted using a hemacytometer and adjusted to $3 \times 10^{5}$ spores $/ \mathrm{ml}$. The host and nonhost leaves were inoculated with the spore suspensions on the lower surfaces of the detached leaves by spraying using an atomizer. Control leaves were sprayed with DW. After inoculation, the leaves were incubated in a moist chamber at $25^{\circ} \mathrm{C}$ in the dark for $24 \mathrm{~h}$, and the number of visible spots $/ \mathrm{cm}^{2}$ was recorded.

Preparation of SGFs. SGFs were collected from cabbage leaves as follows: The lower surfaces of the young cabbage leaves (more than 1 month old) were washed with DW. Drops $(50 \mu \mathrm{l})$ of the spore suspensions of O-265 adjusted to $5 \times 10^{5}$ spores $/ \mathrm{ml}$ were distributed on the lower surface of the leaves supported by a sponge mat in a moist chamber and incubated for different times at $25^{\circ} \mathrm{C}$ in the dark. The drops containing spores were collected and centrifuged at $800 \times g$ for $5 \mathrm{~min}$. The supernatant was used immediately as SGF passed through a $0.22-\mu \mathrm{m}$-pore filter (Millipore, Bedford, MA) or stored at $-80^{\circ} \mathrm{C}$ until use. The rate of spore germination at each incubation time was determined by a light microscopy (Nikon, Tokyo, Japan). Furthermore, the SGF was separated into a low molecular weight fraction (LMW) and a high molecular weight fraction (HMW) by ultrafiltration using a $10 \mathrm{kDa}$ molecular-mass cut off membrane (Millipore, Bedford, MA). The SGF and the separated fractions were concentrated 10 -fold using a freeze-dryer (Taitec, Tokyo, Japan) and stored at $-80^{\circ} \mathrm{C}$ until use.

Assay for toxicity. The toxicity of SGFs collected at different times was determined by a detached leaf assay on host and nonhost leaves as described by Otani et al. (20) and Kohmoto (9). The lower surfaces of the leaves were wounded gently with a forceps, and a 40- $\mu$ l drop of the SGF was put on the wounded right side. As a control, the wounded left side was treated with DW. The leaves were incubated for $48 \mathrm{~h}$ on a sponge mat in a moist chamber at $25^{\circ} \mathrm{C}$ in the dark. Water-soaked chlorosis and necrosis that appeared around the wounded sites were recorded as the presence, slight presence, or absence of toxic activity. The toxicity of the LMW and the HMW fractions concentrated 10fold was also examined under the same conditions.

Chemical and heat treatments. The HMW fraction $(0.5 \mathrm{ml})$ at 10 -fold concentration was mixed with $0.5 \mathrm{ml}$ of proteinase $\mathrm{K}$ (Wako, Tokyo, Japan) at concentration of 1,000, 500, 100, 50, 25, and $10 \mu \mathrm{g} / \mathrm{ml}$. The mixed samples were incubated at $32{ }^{\circ} \mathrm{C}$ in a water bath for $7 \mathrm{~h}$. The toxicity of the samples was determined using the detached leaf assay. Proteinase $\mathrm{K}$ alone and the HMW fraction alone incubated under the same conditions were used as controls. To test the effect of heat treatment on the toxic activity of the HMW fraction, samples $(1 \mathrm{ml}$ each $)$ in Eppendorf tubes were incubated in a water bath $\left(40,60\right.$, and $\left.100^{\circ} \mathrm{C}\right)$ for $15 \mathrm{~min}$ and then placed on ice for $10 \mathrm{~min}$. The HMW fraction without heat treatment and maintained on ice was used as a control. The toxicity was determined by the detached leaf assay.

Toxin purification from SGFs. All purification procedures were performed at $4^{\circ} \mathrm{C}$ unless otherwise noted. Firstly, $300 \mathrm{ml}$ of SGFs was passed through a $0.22-\mu \mathrm{m}$-pore filter unit. The HMW fraction separated from SGFs with a $10 \mathrm{kDa}$ membrane was washed three times with DW using a $10 \mathrm{kDa}$ membrane until the yellow coloration was removed, and finally concentrated twofold. After that, powdered $\left(\mathrm{NH}_{4}\right)_{2} \mathrm{SO}_{4}$ was gradually added to the HMW fraction to obtain $20 \%$ saturation with continuous stirring for $1 \mathrm{~h}$, and centrifuged at 5,870 g for $30 \mathrm{~min}$. The supernatant was pooled and subjected to $40,60,80$, and $100 \%$ saturations in a manner similar to that of $20 \%$ saturation. The precipitated proteins were collected, desalted with a 10-kDa membrane, and dissolved in $50 \mathrm{mM}$ Tris- $\mathrm{HCl}$ buffer, $\mathrm{pH}$ 8.0. As the buffers used for purification were not compatible with the leaf assay, samples (1 ml each) of the fractions were desalted with a $10 \mathrm{kDa}$ membrane, dissolved in $20 \mathrm{mM}$ Tris- $\mathrm{HCl}$ buffer, $\mathrm{pH} \mathrm{8.0,} \mathrm{and} \mathrm{tested} \mathrm{for}$ toxicity. As a control, $20 \mathrm{mM}$ Tris- $\mathrm{HCl}$ buffer, $\mathrm{pH} \mathrm{8.0,} \mathrm{was} \mathrm{used.}$

The active fraction was filtered with a syringe-driven filter unit with a $0.45 \mu \mathrm{m}$-pore-size filter (Millipore) and used for ion exchange chromatography (IEC) with a DEAE-Sepharose Fast Flow column $(15.0 \times 1.5 \mathrm{~cm})($ Pharmacia, Uppsala, Sweden) previously equilibrated with $50 \mathrm{mM}$ Tris- $\mathrm{HCl}$ buffer, $\mathrm{pH}$ 8.0. The column was washed with $25 \mathrm{ml}$ of the same buffer and the proteins were eluted from the column with a gradient of $\mathrm{NaCl}(0,0.05,0.1,0.2$, and $0.5 \mathrm{M})$ in $50 \mathrm{mM}$ Tris- $\mathrm{HCl}$ buffer, $\mathrm{pH} 8.0(25 \mathrm{ml})$. The fractions (30 ml each) were collected and tested for toxicity.

The active fractions obtained by IEC were combined and brought to $1.7 \mathrm{M}\left(\mathrm{NH}_{4}\right)_{2} \mathrm{SO}_{4}$ prior to separation by hydrophobic interaction chromatography (HIC) with a Phenyl-Sepharose 6 Fast Flow (high sub) $(15.0 \times 1.5 \mathrm{~cm})(\mathrm{GE}$ Healthcare, Uppsala, Sweden) previously equilibrated with $1.7 \mathrm{M}\left(\mathrm{NH}_{4}\right)_{2} \mathrm{SO}_{4}$ and $50 \mathrm{mM}$ phosphate buffer, $\mathrm{pH}$ 7.0. Before protein elution, the column was washed with $50 \mathrm{ml}$ of equilibrated buffer and proteins were eluted with a gradient of $\left(\mathrm{NH}_{4}\right)_{2} \mathrm{SO}_{4}(1,0.5,0.2$, and $0 \mathrm{M})$ in $50 \mathrm{mM}$ phosphate buffer, $\mathrm{pH}$ 7.0. The eluted fractions $(5 \mathrm{ml} \times 12$ fractions each concentration) were collected and tested for toxicity.

The active fractions obtained by HIC were combined and concentrated by ultrafiltration, and further purification was carried out by gel filtration chromatography (GFC) with Sephadex-G-150 (Pharmacia). The combined fractions $(3 \mathrm{ml})$ was loaded onto the column $(50.0 \times 2.0 \mathrm{~cm})$ equilibrated with $0.15 \mathrm{M} \mathrm{NaCl}$ and 50 $\mathrm{mM}$ Tris- $\mathrm{HCl}$ buffer, $\mathrm{pH} 8.0$. Thirty-fractions of $4.0 \mathrm{ml}$ of each were collected using the SF-2120 Super Fraction Collector (Advantec Toyo, Tokyo, Japan). Each fraction was desalted and toxicity was determined by the detached leaf assay.

For further purification, high performance liquid chromatography (HPLC) was performed in nondenaturing condition. The active fractions collected from GFC were combined and concentrated by ultrafiltration. The combined fraction $(200 \mu \mathrm{l})$ was applied onto a TSK-gel G300SW column $(0.78 \times 30 \mathrm{~cm})($ Tosoh Corporation, Tokyo, Japan) equilibrated with $0.15 \mathrm{M} \mathrm{NaCl}$ and $50 \mathrm{mM}$ Tris- $\mathrm{HCl}$ buffer, $\mathrm{pH}$ 8.0. The proteins were eluted with the buffer at a flow rate of $1 \mathrm{ml} / \mathrm{min}$, measuring the absorbance at $280 \mathrm{~nm}$. The fractions were collected based on the absorbance and assayed for toxicity.

The purification process was carried out four times using 300 $\mathrm{ml}$ of SGF each. The protein concentration was determined by Bradford's method (4) with bovine serum albumin (Sigma, St. Louis, MO) as the standard. 
Electrophoretic analysis. The protein profile was monitored by sodium dodecyl sulfate (SDS)-polyacrylamide gel electrophoresis (PAGE) using a gradient gel 10 to $20 \%$ (wt/vol) acrylamide concentration (Daiichi Pure Chemical, Tokyo, Japan) following Laemmli's method (12). The protein bands were stained with Coomassie brilliant blue R-250 or silver stain (Daiichi Pure Chemical). Molecular weights were estimated by a comparison with the molecular weight markers (Daiichi III, Daiichi Pure Chemical): phosphorylase b $(97.4 \mathrm{kDa})$, bovine serum albumin $(66.2 \mathrm{kDa})$, aldolase $(42.4)$, carbonic anhydrase (30 kDa), trypsin inhibitor $(20.1 \mathrm{kDa})$, and lysozyme $(14.4 \mathrm{kDa})$.

Determination of isoelectric point (pI). To determine the $\mathrm{pI}$ of the toxic protein, the purified protein was applied to a Phast System apparatus (Pharmacia) using PhastGel IEF 3-9 (GE Healthcare, Uppsala, Sweden) following the manufacturer's instructions. The IEF gels were silver-stained in the PhastSystem Development Unit with PlusOne Silver Staining Kit (GE Healthcare). The pI value was determined using a broad $\mathrm{pI}$ calibration kit, $\mathrm{pH} 3$ to 10 (GE Healthcare).

N-terminal amino acid sequence. The proteins separated by SDS-PAGE were electroblotted onto a polyvinyliden difluoride (PVDF) transfer membrane (ATTO, Tokyo, Japan). The protein band $(27.5 \mathrm{kDa})(10 \mu \mathrm{g})$ was excised from the membrane sheet and used for amino acid sequencing according to Edman's method with a protein sequencer (Applied Biosystems, Foster City, CA).

Effect of heat treatment on activity of purified toxin. The effect of heat treatment on the toxicity of the active fraction collected from GFC was determined by the detached leaf assay.

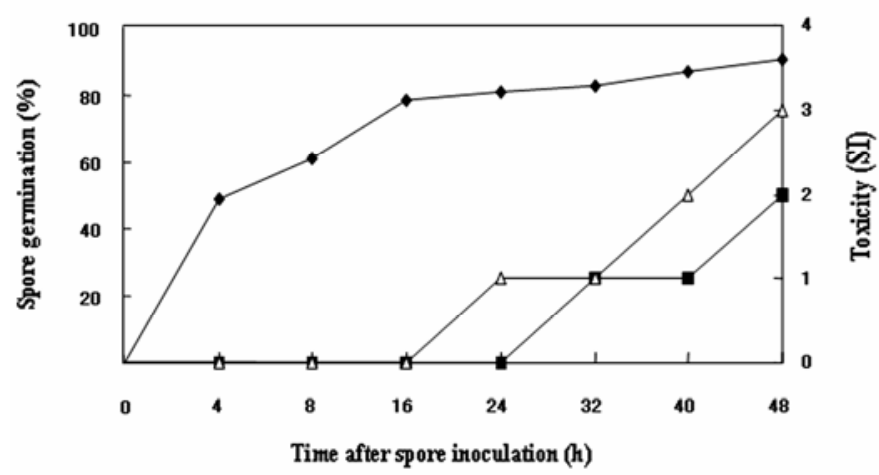

Fig. 1. Time course of toxin production in spore germination fluids (SGFs) of Alternaria brassicae (O-265). The percent spore germination was determined under a microscope $(\diamond)$. The filtered SGFs $(\mathbf{\square})$ and the SGFs concentrated fivefold $(\triangle)$ were assayed for symptom intensity (SI), 0: no symptom, 1: symptoms on less than $25 \%$ of the leaf, 2 : symptoms covering 25 to $50 \%$ of the leaf, and 3: symptoms covering 50 to $100 \%$ of the leaf.

The toxin samples in $20 \mathrm{mM}$ Tris- $\mathrm{HCl}$ buffer, $\mathrm{pH} 8.0$, were treated at different temperatures ranging from room temperature $\left(25 \pm 2^{\circ} \mathrm{C}\right.$ ) to $60^{\circ} \mathrm{C}$ for $15 \mathrm{~min}$, and then placed on ice for $10 \mathrm{~min}$. As a control, the leaves were treated with the purified sample maintained on ice.

Toxicity and infection-inducing activity of purified toxin. The purified protein toxin was serially diluted with a $20 \mathrm{mM}$ Tris$\mathrm{HCl}$ buffer ( $\mathrm{pH}$ 8.0). The toxicity of the dilutions was determined by the detached leaf assay. As controls, the leaves were treated with $20 \mathrm{mM}$ Tris- $\mathrm{HCl}$ buffer, $\mathrm{pH}$ 8.0. To investigate the infectioninducing activity of the purified protein, the spores of O-94, a nonpathogenic isolate of $A$. alternata, were used. The serial dilutions prepared in the assay for toxicity were used for infectioninducing activity. The spores of the isolate O-94 were washed and pelleted by centrifugation at $800 \times g$ for $10 \mathrm{~min}$. Then, the spores were suspended in each serial dilution at the same density $(5 \times$ $10^{5}$ spores $\left./ \mathrm{ml}\right)$. The spore suspensions were placed $(50 \mu \mathrm{l})$ on the lower surfaces of the leaves without wounding. As a control, leaves were inoculated with spores of O-94 suspended in $20 \mathrm{mM}$ Tris- $\mathrm{HCl}$ buffer, $\mathrm{pH} 8.0$, at the same density.

A

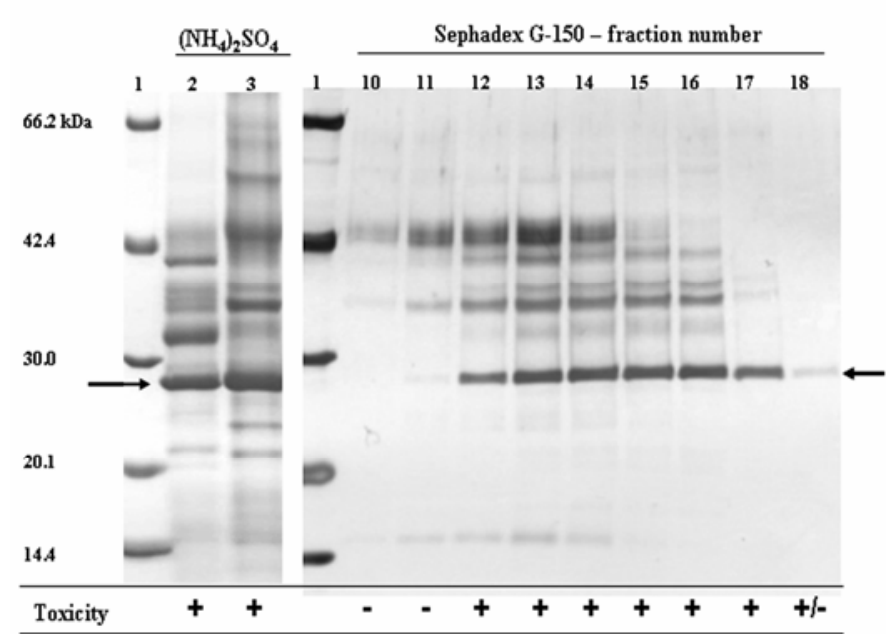

Fig. 2. Sodium dodecyl sulfate-polyacrylamide gel electrophoresis (SDSPAGE) of toxic fractions obtained by Phenyl 6 Fast Flow hydrophobic interaction chromatography (HIC) and gel filtration chromatography (GFC). A, SDS-PAGE of the toxic fractions collected after HIC. Lanes: 1, molecularmass standard; 2, $1 \mathrm{M}\left(\mathrm{NH}_{4}\right)_{2} \mathrm{SO}_{4}$ eluent; 3, $0.5 \mathrm{M}\left(\mathrm{NH}_{4}\right)_{2} \mathrm{SO}_{4}$ eluent. B, SDSPAGE of the toxic fractions collected after GFC. Lanes: 1, molecular-mass standard; 10 to 18 , fraction numbers collected from gel filtration. The toxicity was recorded as $(+)$ : presence of toxicity, $(+/-)$ : presence of slight toxicity and $(-)$ : absence of toxicity. The black arrows indicate the band of $27.5 \mathrm{kDa}$ associated with toxicity.

TABLE 1. Pathogenicity of Alternaria brassicae (O-265) and toxicity of spore germination fluids (SGFs) on Brassica and other species

\begin{tabular}{|c|c|c|c|c|c|}
\hline \multirow[b]{2}{*}{ Plant } & \multirow[b]{2}{*}{ Pathogenicity $^{\mathrm{a}}\left(\right.$ spots $\left./ \mathrm{cm}^{2}\right)$} & \multicolumn{4}{|c|}{ Toxicity $^{\mathrm{b}}$} \\
\hline & & SGF & LMW & HMW & DW \\
\hline \multicolumn{6}{|l|}{ Host } \\
\hline Cabbage & $40.2 \pm 3.1$ & $++(\mathrm{W})$ & $+(\mathrm{C})$ & $+(\mathrm{W})$ & - \\
\hline Komatsuna & $26.2 \pm 4.0$ & $++(\mathrm{W})$ & $+(\mathrm{C})$ & $+(\mathrm{W})$ & - \\
\hline Oilseed & $24.0 \pm 5.0$ & $++(\mathrm{W})$ & $+(\mathrm{C})$ & $+(\mathrm{W})$ & - \\
\hline \multicolumn{6}{|l|}{ Nonhost } \\
\hline Apple & 0.0 & $++(\mathrm{N})$ & $+(\mathrm{N})$ & - & - \\
\hline Japanese pear & 0.0 & $++(\mathrm{N})$ & $+(\mathrm{N})$ & - & - \\
\hline Tomato & 0.0 & $++(\mathrm{C})$ & $+(\mathrm{C})$ & - & - \\
\hline
\end{tabular}




\section{RESULTS}

Toxicity of SGF. The spore suspensions of O-265 were placed on cabbage leaves (cv. Shoshu) and the spore germination and toxicity of SGF were examined after incubation for different times. As shown in Figure 1, the spore germination on cabbage leaves reached approximately $50 \%$ at $4 \mathrm{~h}$ after inoculation, and more than $80 \%$ of the spores had germinated $24 \mathrm{~h}$ after inoculation. The SGFs recovered at different times and the SGFs concentrated fivefold were assayed for toxicity on cabbage leaves. The toxicity was first detected in the SGF concentrated fivefold after $24 \mathrm{~h}$ of inoculation and the activity increased with time until $48 \mathrm{~h}$. The original SGF showed toxicity after $32 \mathrm{~h}$ of inoculation. When the SGF was concentrated 10-fold, slight symptoms were detected after $16 \mathrm{~h}$, but not after $8 \mathrm{~h}$ (data not shown). Therefore, the SGF collected after $48 \mathrm{~h}$ of inoculation was used in further experiments.

The pathogenicity test by spore inoculation showed that O-265 of $A$. brassicae caused small dark brown spots on host plant leaves at $24 \mathrm{~h}$ after inoculation (Table 1), and the spots were surrounded by a chlorotic halo after $48 \mathrm{~h}$ of inoculation. No lesions were observed on nonhost plants inoculated with the same pathogen. In the toxicity test, the SGF concentrated 10-fold induced water-soaked symptoms followed by chlorosis on host leaves, and necrosis or chlorosis on nonhost leaves depending on the plant. When the SGF was separated into LMW and HMW fractions with a $10-\mathrm{kDa}$ membrane, the LMW fraction induced only chlorosis on host leaves and necrosis or chlorosis on nonhost leaves. Whereas the HMW fraction induced water-soaked symptoms followed by chlorosis only on host leaves (Table 1). In both

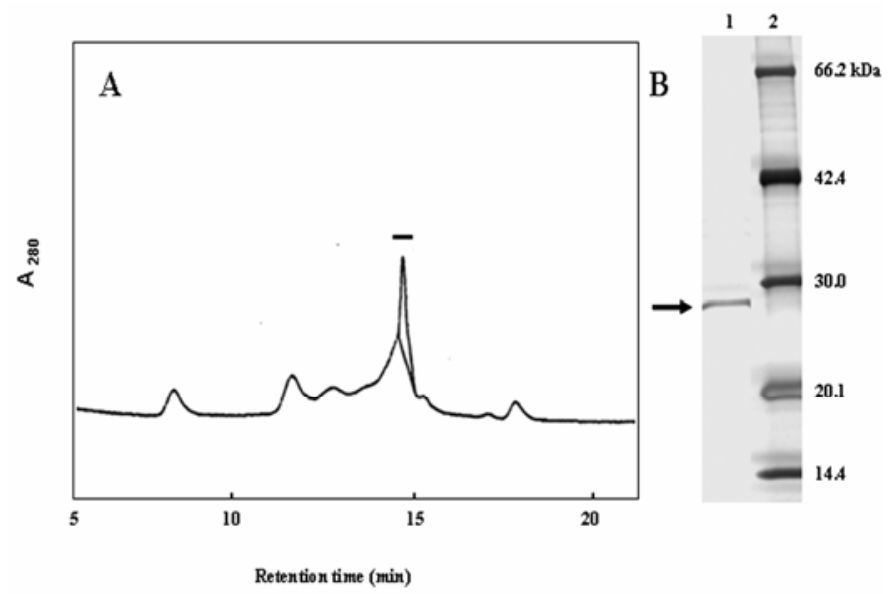

Fig. 3. Gel filtration high-performance liquid chromatography (HPLC) on a TSK-gel G300SW column. A, HPLC profiles of the toxic fraction. The solid bar indicates the fraction containing toxicity. B, Sodium dodecyl sulfate-polyacrylamide gel electrophoresis of the toxic fraction collected from HPLC. Lane 1, toxic fraction; lane 2, molecular-mass standard. The black arrow indicates the band of $27.5 \mathrm{kDa}$ corresponding to the protein toxin. pathogenicity and toxicity tests, the leaves treated with DW did not show any symptoms. The toxicity of the HMW fraction was lost after heating at $60^{\circ} \mathrm{C}$ for $15 \mathrm{~min}$ or treatment with proteinase $\mathrm{K}$ at $100 \mu \mathrm{g} / \mathrm{ml}$ at $32^{\circ} \mathrm{C}$ for $7 \mathrm{~h}$ (data not shown), indicating the presence of host-specific protein toxin(s) in SGF collected from cabbage leaves.

Purification of protein toxin from SGF. Host-specific toxicity was detected in the HMW fraction precipitated at 60 to $80 \%$ $\left(\mathrm{NH}_{4}\right)_{2} \mathrm{SO}_{4}$ saturation. This fraction induced symptoms in Brassica leaves at a concentration of $10 \mu \mathrm{g} / \mathrm{ml}$, but not on the nonhost leaves even at a high concentration $(150 \mu \mathrm{g} / \mathrm{ml})$ (data not shown). Four chromatography steps (IEC, HIC, GFC, and HPLC) were employed to purify the protein toxin. The results of the detached leaf assay with different fractions collected from IEC indicated that the unbound fraction (wash-buffer) and the bound fraction eluted with $0.05 \mathrm{M} \mathrm{NaCl}$ were toxic, whereas toxicity was not detected in the bound fractions eluted at $0.1,0.2$, and $0.5 \mathrm{M} \mathrm{NaCl}$ despite high protein content (data not shown). Further purification by $\mathrm{HIC}$ with a gradient of $\left(\mathrm{NH}_{4}\right)_{2} \mathrm{SO}_{4}$ showed that the fractions eluted with 1 and $0.5 \mathrm{M}\left(\mathrm{NH}_{4}\right)_{2} \mathrm{SO}_{4}$ were toxic. No toxicity was observed in the fractions eluted with 0.2 and $0 \mathrm{M}\left(\mathrm{NH}_{4}\right)_{2} \mathrm{SO}_{4}$. By SDS-PAGE, a clear band of $27.5 \mathrm{kDa}$ was observed in both of the two active fractions (Fig. 2A).

The toxic fractions obtained by HIC were combined and further purified by GFC. The results showed that among the 30 fractions tested for toxicity, the activity was detected in the fractions 12 to 17 , and a trace of activity was observed in fraction 18 . The toxi-

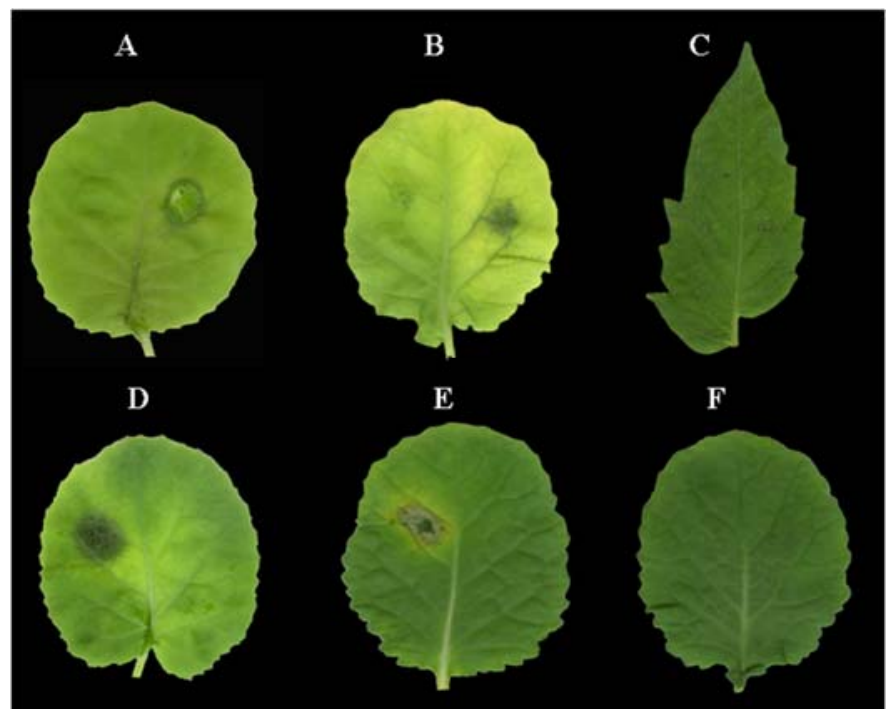

Fig. 4. Response of detached leaves treated with the toxin and inoculated with the spores of nonpathogenic Alternaria alternata suspended in the toxin. The solution was placed on the wounded detached leaves. A, Cabbage (cv. Shoshu), B, oilseed (cv. Westar), and C, tomato (cv. Momotaro). Spore suspensions were placed on detached leaves without a wound. D, Inoculation with O-265, E, inoculation with O-94 suspended in the toxin, and $\mathbf{F}$, inoculation with O-94 suspended in buffer.

TABLE 2. Toxicity of the purified protein toxin to Brassica and other plant leaves

\begin{tabular}{|c|c|c|c|c|c|c|c|c|}
\hline \multirow[b]{3}{*}{ Plant } & \multicolumn{8}{|c|}{ Toxicity $^{\mathrm{a}}$} \\
\hline & \multicolumn{7}{|c|}{ Toxin concentration $(\mu \mathrm{g} / \mathrm{ml})$} & \multirow[b]{2}{*}{ Buffer } \\
\hline & 50 & 25 & 10 & 5 & 1 & 0.5 & 0.1 & \\
\hline Cabbage & ++ & ++ & ++ & + & + & $+/-$ & - & - \\
\hline Oilseed & +++ & +++ & ++ & ++ & + & $+1-$ & - & - \\
\hline Tomato & - & - & - & - & - & - & - & - \\
\hline
\end{tabular}

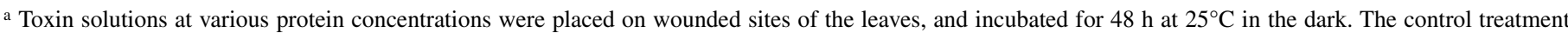
was drops of buffer $(20 \mathrm{mM}$ Tris- $\mathrm{HCl}$ buffer, $\mathrm{pH} 8.0)$. The toxicity was evaluated as symptoms covering $50-100 \%$ of the leaf $(+++)$, symptoms covering 25 to $50 \%$ of the leaf $(++)$, symptoms on less than $25 \%$ of the leaf $(+)$, symptoms only around the wounded site $(+/-)$, or no symptom $(-)$. 
city of the fractions was associated with a band of $27.5 \mathrm{kDa}$ as shown by SDS-PAGE (Fig. 2B). The toxic fractions from GFC were combined and analyzed by HPLC (Fig. 3A). A major UVabsorbing peak detected at the retention time of 14.05 min was collected and tested for toxicity. The three small peaks before and one peak after the major peak were also collected and tested for toxicity. The results showed that only the major peak at the retention time of 14.05 min caused water-soaked symptoms within $24 \mathrm{~h}$ on host leaves.

Characteristics of the protein toxin. The molecular weight of the toxin purified by HPLC was estimated by SDS-PAGE to be $27.5 \mathrm{kDa}$ (Fig. 3B). When the purified protein toxin was submitted to amino acid sequencing, the $\mathrm{N}$ terminus was not blocked, and the sequence of the N-terminal 21 amino acid residues was Ile-Val-Gly-Gly-Val-Pro-Ala-Val-Thr-Gly-Asp-Leu-Leu-Pro-TyrLys-Val-Ser-Val-Ala-Arg. Analysis of the N-terminal peptide sequence obtained from FASTA search revealed that it has $81 \%$ similarity in 21 amino acid overlap with trypsin precursor (P35049) from Fusarium oxysporum. In nondenaturing conditions, the $\mathrm{pI}$ of the purified protein toxin was approximately 7.0 (data not shown).

The toxic fraction obtained by GFC was tested for toxicity after treatment at various temperatures. The toxicity of the protein toxin was stable at room temperature and after heating at $40^{\circ} \mathrm{C}$ for $15 \mathrm{~min}$. However, the activity was completely destroyed after heating at $60^{\circ} \mathrm{C}$ for $15 \mathrm{~min}$. The protein toxin maintained toxic activity after being stored for 6 months at $-20^{\circ} \mathrm{C}$ (data not shown).

Toxicity and infection-inducing activity of the purified protein toxin. The purified protein toxin was serially diluted with $20 \mathrm{mM}$ Tris-HCl buffer ( $\mathrm{pH}$ 8.0) and tested for toxicity. The toxin applied at $0.1 \mu \mathrm{g} / \mathrm{ml}$ failed to produce symptoms on host leaves at any time. However, at $1.0 \mu \mathrm{g} / \mathrm{ml}$, visible water-soaking and chlorosis on host leaves were observed after $48 \mathrm{~h}$ of incubation, and slight symptoms were observed at $0.5 \mu \mathrm{g} / \mathrm{ml}$, which induced clear symptoms after $72 \mathrm{~h}$ of incubation (Table 2). The lesion area on host leaves expanded gradually with the increase of toxin concentrations. No symptoms were observed on host and nonhost leaves treated with buffer as a control or on nonhost leaves treated with the toxin at $50 \mu \mathrm{g} / \mathrm{ml}$ (Table 2 and Fig. 4).

The effect of the purified protein toxin on the infection of a nonpathogenic isolate of A. alternata (O-94) was investigated. When spores of O-94 were suspended in the purified toxin at more than $0.5 \mu \mathrm{g} / \mathrm{ml}$ and placed on the lower surfaces of leaves without any wound, the spores were able to infect host leaves similar to spores of $A$. brassicae (O-265), inducing water-soaked symptoms followed by chlorosis after $48 \mathrm{~h}$ of incubation (Table 3 and Fig. 4). However, the toxin did not enable O-94 spores to colonize nonhost leaves even at $50 \mu \mathrm{g} / \mathrm{ml}$. Infection was not observed when the leaves were inoculated with O-94 spores suspended in buffer (Table 3 and Fig. 4). Symptoms did not appear on detached host leaves without a wound treated with the toxin alone at $50 \mu \mathrm{g} / \mathrm{ml}$ (Table 3).

\section{DISCUSSION}

A. brassicae has a wide host range including most cruciferous crops throughout the world, often resulting in severe yield losses $(7,8)$. Considerable efforts have been made to study the toxic metabolites produced by $A$. brassicae, which are important in the interaction between host plants and pathogen $(2,3,5,25)$. In this study, we found that $A$. brassicae produces a new HST named ABR-toxin that causes water-soaked symptoms followed by chlorosis only in Brassica leaves. The toxin in SGF collected after inoculation of $A$. brassicae on host leaves was retained by ultrafiltration with a $10 \mathrm{kDa}$ cut off membrane, and the activity was abolished by heat and proteinase $\mathrm{K}$ treatments, indicating that unlike other toxins reported to be produced by A. brassicae (1$3,5,25)$, the new toxin appeared to be a protein. Ammonium sulfate fractionation and IEC were effective purification steps for removing the yellow coloration and many contaminating proteins without any toxicity. The toxin partially purified by HIC showed a common band of $27.5 \mathrm{kDa}$ by SDS-PAGE and this band was associated with the toxicity on host plants. Finally, GFC and HPLC confirmed that the $27.5-\mathrm{kDa}$ protein was associated with the toxicity. Approximately $15.3 \mu \mathrm{g}$ of the purified protein was obtained from $300 \mathrm{ml}$ of SGF.

The successful purification of ABR-toxin allowed us to investigate its biological activities as an HST and its chemical characteristics. ABR-toxin at concentrations of 0.5 to $1.0 \mu \mathrm{g} / \mathrm{ml}$ induced water-soaked symptoms followed by chlorosis on Brassica leaves, while nonhost leaves were not affected even at $50 \mu \mathrm{g} / \mathrm{ml}$, suggesting a host-specific toxicity. On the other hand, as reported by many researchers, the key role of HSTs in initial colonization is not to kill host cells prior to penetration but to predispose the host cells beneath germinating spores to accept penetration $(6,10,19$, 30). The toxin at 0.5 to $1.0 \mu \mathrm{g} / \mathrm{ml}$ also enabled colonization by a nonpathogenic A. alternata to occur only in Brassica plants suggesting that the toxin induces accessibility of host plants to fungal invasion. These data indicated that ABR-toxin from A. brassicae fits the criteria of HST and plays a key role as a disease determinant of A. brassicae. This is the first report of a protein HST from $A$. brassicae.

To date, two other protein HSTs from Alternaria spp. have been reported, AB-toxin produced by A. brassicicola, the causal agent of black spot disease of Brassica plants (20), and AP-toxin produced by $A$. panax, the causal agent of Alternaria blight of American ginseng (23). Although both protein HSTs are the same molecular weight (35 kDa), AP-toxin does not induce any symptoms on hosts of $A$. brassicicola, indicating that the AP-toxin produced by $A$. panax is different from the AB-toxin produced by A. brassicicola (23). A. brassicae and A. brassicicola pathogenic to Brassica plants have a similar host range, and ABR-toxin and AB-toxin have similar host-specific activity, but differ in molecular weight. In future research it will be important to investigate the mode of action of ABR-toxin and AB-toxin on host plants.

TABLE 3. Infection-inducing activity of the purified protein toxin to a nonpathogenic isolate of Alternaria alternata (O-94)

\begin{tabular}{|c|c|c|c|c|c|c|c|c|c|}
\hline \multirow[b]{3}{*}{ Plant } & \multicolumn{8}{|c|}{ Infection of O-94 spores $^{\mathrm{a}}$} & \multirow{3}{*}{$\begin{array}{l}\text { Treatment with } \\
50 \mu \mathrm{g} / \mathrm{ml} \text { toxin }^{\mathrm{b}}\end{array}$} \\
\hline & \multicolumn{8}{|c|}{ Toxin concentration $(\mu \mathrm{g} / \mathrm{ml})$} & \\
\hline & 50 & 25 & 10 & 5 & 1 & 0.5 & 0.1 & Buffer & \\
\hline Cabbage & +++ & ++ & + & + & + & $+/-$ & - & - & - \\
\hline Oilseed & +++ & ++ & + & + & + & $+/-$ & - & - & - \\
\hline Tomato & - & - & - & - & - & - & - & - & - \\
\hline
\end{tabular}


ABR-toxin was produced by A. brassicae in SGF collected from host leaves, but not from SGF collected from nonhost leaves or petri plates, indicating that host factors may be involved in ABR-toxin production. A similar host requirement has been reported for production of AB-toxin (20) and AP-toxin (23). Recently, Oka et al. (16) reported that production of AB-toxin by germinating spores of $A$. brassicicola is induced by recognition of a host-derived oligosaccharide of $1.3 \mathrm{kDa}$. The same oligosaccharide derived from host leaves may be involved in the production of ABR-toxin by germinating spores of A. brassicae.

Several studies have reported that destruxin B is involved in the development of gray leaf spot in Brassica plants $(1-3,5,25)$. In this study, when the nonpathogenic spores of A. alternata mixed with ABR-toxin were inoculated onto leaves, brown spots followed by chlorosis similar to the symptoms seen during infection by A. brassicae appeared on Brassica leaves. Therefore, ABRtoxin does not only induce the initial colonization in host plants, but also seems to be involved in disease development.

In this study, although the complete amino acid sequence of ABR-toxin was not determined, the sequence of the N-terminal 21 amino acid residues indicated high similarity with trypsin precursor from $F$. oxysporum in sequence database search. Therefore, the cloning of a gene encoding ABR-toxin is presently being undertaken.

\section{ACKNOWLEDGMENTS}

We thank H. Shiomi (Takii \& Co. Ltd., Japan) for providing the isolate $\mathrm{O}-265$ of A. brassicae. This work was supported by a fellowship from the Ministry of Education, Culture, Sports, Science, and Technology of Japan to R. Y. Parada.

\section{LITERATURE CITED}

1. Agarwal, A., Garg, G. K., Sing, U. S., and Mishra, D. P. 1994. Detection and role of chlorotic toxin and phytohormones in the pathogenesis of Alternaria blight in Brassica napus. Curr. Sci. 66:442-443.

2. Ayer, W. A., and Peña-Rodriguez, L. M. 1987. Metabolites produced by Alternaria brassicae, the black spot pathogen of canola. Part 1, The phytotoxic components. J. Nat. Prod. 50:400-407.

3. Bains, P. S., and Tewari, J. P. 1987. Purification, chemical characterization and host-specificity of the toxin produced by Alternaria brassicae. Physiol. Mol. Plant Pathol. 30:259-271.

4. Bradford, M. M. 1976. A rapid and sensitive method for quantification of microgram quantities of protein utilizing the principle of protein-dye binding. Anal. Biochem. 72:248-254.

5. Buchwaldt, L., and Green, H. 1992. Phytotoxicity of destruxin B and its possible role in the pathogenesis of Alternaria brassicae. Plant Pathol. 41:55-63.

6. Comstock, J. C., and Scheffer, R. P. 1973. Role of host-selective toxin in colonization of corn leaves by Helminthosporium carbonum. Phytopathology 63:1232-1238.

7. Conn, K. L., Tewari, J. P., and Awasthi, R.P. 1990. A disease assessment key for Alternaria blackspot in rapeseed and mustard. Can. Plant Dis. Surv. 70:19-22.

8. Cooked, D. E. L., Jenkins, P. D., and Lewis, D. M. 1997. Production of phytotoxic spore germination liquids by Alternaria brassicae and $A$. brassicicola and their effect on species of the family Brassicaceae. Ann. Appl. Biol. 131:413-426.

9. Kohmoto, K. 1992. Determination of host-selective toxins. Pages 51-73 in: Modern Methods of Plant Analysis. H. F. Linskens, and J. F. Jackson, eds. Springer-Verlag, Berlin.
10. Kohmoto, K., Otani, H., Kodama, M., and Nishimura, S. 1989. Hostrecognition: Can accessibility to fungal invasion be induced by hostspecific toxins without necessitating necrotic cell death? Pages 249-265 in: Phytotoxins and Plant Pathogenesis. A. Graniti, R. D. Durbin, and A. Ballio, eds. Springer-Verlag, Berlin.

11. Kohmoto, K., Otani, H., and Tsuge, T. 1995. Alternaria alternata pathogens. Pages 51-63 in: Pathogenesis and Host Specificity in Plant Diseases: Histological, Biochemical, Genetic and Molecular Bases, Vol. II: Eukaryotes. K. Kohmoto, U. S. Shin, and R. P Shin, eds. Pergamon Press, Oxford.

12. Laemmli, U. K. 1970. Cleavage of structural proteins during the assembly of the head of bacteriophage T4. Nature 227:680-685.

13. Nishimura, S., and Kohmoto, K. 1983. Host-specific toxins and chemical structures from Alternaria species. Annu. Rev. Phytopathol. 21:87-116.

14. Nishimura, S., and Kohmoto, K. 1983. Roles of toxins in pathogenesis. Pages 137-157 in: Toxins and Plant Pathogenesis. J. M. Daly and B. J. Deverall, eds. Academic Press, Sydney.

15. Nishimura, S., Kohmoto, K., and Otani, H. 1979. The role of host-specific toxins in saphophytic pathogens. Pages 133-146 in: Recognition and Specificity in Plant Host-Parasite Interaction. J. M. Daly, and I. Uritani, eds. Japan Scientific Societies Press, Tokyo, and University Park Press, Baltimore.

16. Oka, K., Akamatsu, H., Kodama, M., Nakajima, H., Kawada, T., and Otani, H. 2005. Host-specific AB-toxin production by germinating spores of Alternaria brassicicola is induced by a host-derived oligosaccharide. Physiol. Mol. Plant Pathol. 66:12-19.

17. Otani, H., Kodama, M., and Kohmoto, K. 1996. Physiological and molecular aspect of Alternaria host-specific toxin and plant interactions. Pages 257-267 in: Molecular Aspects of Pathogenicity and Resistance: Requirement for Signal Transduction. D. Mills, H. Kunoh, N. T. Keen, and S. Mayama, eds. American Phytopathological Society, St. Paul, MN.

18. Otani, H., and Kohmoto, K. 1992. Host-specific toxin of Alternaria species. Pages 123-156 in: Alternaria: Biology, Plant Diseases and Metabolites. J. Chelkowski, and A. Visconti, eds. Elsevier, Amsterdam.

19. Otani, H., Kohmoto, K., Nishimura, S., Nakashima, T., Ueno, T., and Fukami, H. 1985. Biological activities of AK-toxins I and II, host-specific toxins from Alternaria alternata Japanese pear pathotype. Ann. Phytopathol. Soc. Jpn. 51:285-293.

20. Otani, H., Kohnobe, A., Kodama, M., and Kohmoto, K. 1998. Production of a host-specific toxin by germinating spores of Alternaria brassicicola. Physiol. Mol. Plant Pathol. 52:285-95.

21. Parada, R. Y., Oka, K., Yamagishi, D., Kodama, M., and Otani, H. 2007. Destruxin B produced by Alternaria brassicae does not induce accessibility of host plants to fungal invasion. Physiol. Mol. Plant Pathol. (in press).

22. Pringle, R. B., and Scheffer, R. P. 1964. Host-specific plant toxins. Annu. Rev. Phytopathol. 2:133-156.

23. Quayyum, H. A., Gijzen, M., and Tranquair, J. A. 2003. Purification of a necrosis-inducing, host specific protein toxin from spore germination fluid of Alternaria panax. Phytopathology 93:323-328.

24. Scheffer, R. P., and Livingston, R. S. 1984. Host-selective toxins and their role in plant diseases. Science 223:17-21.

25. Tewari, J. P., and Bains, P. S.1997. Phytotoxins produced by Alternaria brassicae and bioassay of destruxin B. Pages 21-35 in: Toxins in Plant Disease Development and Evolving Biotechnology. K. Rajeev and K. G. Mukerji, eds. Science Publisher, Enfield, NH.

26. Thomma, B. P. H. J. 2003. Alternaria spp.: From general saprophyte to specific parasite. Mol. Plant Pathol. 4:225-236.

27. Walton, J. D. 1996. Host-selective toxins: Agents of compatibility. Plant Cell 8:1723-1733.

28. Wolpert, T. J., Dunkle, L. D., and Ciuffetti, L. M. 2003. Host-selective toxins and avirulence determinats: What's in a name? Annu. Rev. Phytopathol. 40:251-285.

29. Yoder, O. C. 1980. Toxins in pathogenesis. Annu. Rev. Phytopathol. 18:103-129.

30. Yoder, O. C., and Scheffer, R. P. 1969. Role of toxin in early interactions of Helminthosporium victoriae with susceptible and resistant oat tissue. Phytopathology 59:1954-1959. 